TERMINUS

t. 20 (2018), z. 3 (48), s. 383-401

doi: 10.4467/20843844TE.18.018.10087

www.ejournals.eu/Terminus

Justyna Kiliańczyk-Zięba

Uniwersytet Jagielloński, Kraków

justynakz@gmail.com

Edycja

Katarzyna Gara

km.gara@gmail.com

Tłumaczenie z języka łacińskiego

http://orcid.org/0000-0001-6592-4747

\title{
Listy Jana Januszowskiego do Marcina Kromera i Tomasza Płazy dotyczące produkcji Missale Varmiense (1587) w Drukarni Łazarzowej ${ }^{1}$
}

\begin{abstract}
Jan Januszowski's letters to Marcin Kromer and Tomasz Płaza on printing Missale Varmiense (1587) in Officina Lazari
\end{abstract}

Officina Lazari was one of the most prominent printing houses in the $16^{\text {th }}$-century Cracow. In 1587, it pressed Missale Varmiense, the only post-Tridentine missal produced in early modern Poland-Lithuania. Missale was commissioned by the bishop of Warmia, Marcin Kromer, who was persuaded to work with the Cracow printer after a recommendation from Tomasz Płaza, his long-time assistant. The history of this publishing venture-a multifaceted, dynamic process, spread over

1 Autorki dziękują ks. prof. Andrzejowi Kopiczce za ułatwienie kwerendy w zbiorach Archiwum Archidiecezji Warmińskiej w Olsztynie oraz prof. Januszowi S. Gruchale, dr hab. Grażynie Urban-Godziek i dr. hab. Maciejowi Zdankowi. 
a period of about five years-can be reconstructed thanks to surviving archival documents, inter alia letters that Januszowski-the printer sent to bishop Kromer and his factotum Płaza. Composed respectively in 1585 and 1586, these letters give detailed insight into how the production of Missale Varmiense was planned and organised, constituting the kind of evidence very rare for early printed books produced in Poland-Lithuania. The earlier letter is an official Latin supplication sent by the printer to the prelate. The other letter, addressed to the bishop's assistant, who was also the manager of the publishing process is practically oriented and personal, written at the time when the work of Januszowski and his sponsors was put to a halt by the Cracow cathedral chapter in the spring of 1586.

Keywords: early modern book culture, book history, printed book production, post-Tridentine missal, Krakow/Cracow printing

Jan Łazarzowic Januszowski (1555-1613) był jednym z najważniejszych drukarzy dawnej Rzeczypospolitej. Krakowska Drukarnia Łazarzowa, oficyna o tradycjach sięgających początku XVI wieku, działała pod jego kierownictwem od 1578 roku, drukując ponad czterysta znanych dziś edycji w niemal dziewięciu tysiącach arkuszy. Januszowski drukarnię przejął po swym ojcu Łazarzu Andrysowicu. Ten zaś stał się właścicielem przedsiębiorstwa dzięki małżeństwu z Barbarą, wdową po Hieronimie Wietorze, który w Krakowie drukował w latach 1518-1546. Łazarzowic, już w latach 70. XVI wieku używający nazwiska Januszowski, był synem Barbary Wietorowej i jej niegdysiejszego czeladnika. Wykształcenie zdobył w służbie dworskiej (pracował m.in. jako pisarz Zygmunta Augusta i w kancelarii Stefana Batorego) oraz podczas studiów uniwersyteckich w Krakowie i Padwie. Miał ambicje pisarskie i translatorskie, a w swej oficynie chciał produkować nie tylko druki pokupne, ale też książki piękne i nowoczesne, podobne do tych, które schodziły z pras potentatów na ówczesnym rynku wydawniczym².

2 A. Kawecka-Gryczowa, Jan Januszowski, w: Drukarze dawnej Polski od XV do XVIII wieku, t. 1: Małopolska, cz. 1: Wiek XV-XVI, red. A. Kawecka-Gryczowa, 
Prowadząc Drukarnię Łazarzową, Januszowski, rzutki i obyty, utrzymywał ze współczesnymi rozległą korespondencję. Pisać musiał choćby do autorów, których utwory tłoczyła jego oficyna. Byli wśród nich najwybitniejsi w Rzeczypospolitej ludzie pióra: poeci, polemiści, kaznodzieje, historycy, filologowie i tłumacze. Jednocześnie, na przykład zabiegając o zlecenia na produkcję druków urzędowych i ksiąg kościelnych, Januszowski stukał do drzwi możnych - dygnitarzy świeckich i duchownych - i słał do nich listy pisane po polsku i po łacinie.

Śladów tych epistolograficznych kontaktów drukarza - humanisty i przedsiębiorcy - zachowało się jednak niewiele. Pośrednie i fragmentaryczne świadectwa o korespondencji z Janem Kochanowskim, Łukaszem Górnickim, samym królem Stefanem Batorym „i inszemi” zawdzięczamy Januszowskiemu. W dedykacji dzieł zebranych poety z Czarnolasu (1585/1586) drukarz usprawiedliwiał zamieszczenie w zbiorze swawolnych fraszek cytatem $\mathrm{z}$ listu Kochanowskiego („pisałem o to do niego. Na co potym odpisał mi w te słowa [...]”3). Później, w Nowym karakterze polskim (1594), Januszowski wspominał poetę, „który mało co przed śmiercią swoją, jako o rzeczach inszych, tak i o tej polskiej ortografijej, którą w drukarni baczył mojej i w liściech moich, począł był ze mną konferować". Cytował tu także obszerny passus z listu Górnickiego („napisawszy te słowa do mnie w liście swoim $[\ldots] "]^{5}$ i przywoływał otrzymywane od niego prze-

Wrocław 1983, s. 69-99; R. Żurkowa, Jan Januszowski, w: Drukarze..., t. 1: Małopolska, cz. 2: Wiek XVII-XVIII, vol. 1, red. J. Pirożyński, Kraków 2000, s. 250-257; R. Żurkowa, Łazarzowa Drukarnia, w: Drukarze..., t. 1: Małopolska, cz. 2: Wiek XVII-XVIII, vol. 2, red. J. Pirożyński, Kraków 2000, s. 411-412; J. Kiliańczyk-Zięba, Czcionką i piórem. Jan Januszowski w roli pisarza i tłumacza, Kraków 2007.

3 J. Januszowski, [list dedykacyjny do J. Myszkowskiego], w: Jan Kochanowski, Kraków: Drukarnia Łazarzowa, 1585/1586, s. k. *iii, cyt. za: J. Kochanowski, Dzieta wszystkie, Wydanie sejmowe, tom wstępny: Wprowadzenie wydawnicze, oprac. M.R. Mayenowa, J. Woronczak, M. Kaczmarek, E. Głębicka (Biblioteka Pisarzów Polskich, seria B, nr 22), Wrocław 1983, s. 166.

k. D3r.

4 J. Januszowski, Nowy karakter polski, Kraków: Drukarnia Łazarzowa, 1594,

5 Ibidem, k. D3v. 
syłki. W dedykacji Nowego karakteru Januszowski pisał, że wsparcia dla swoich wydawniczych prac poszukiwał u wielu możnych, deklarując zawsze chęć poświęcenia dla Kościoła i ojczyzny: „z czym jakom się przed onym wiecznej pamięci i nieśmiertelnej sławy królem wielkim Stefanem i przed inszemi często a gęsto ustnie i listownie opowiadał"6. W tym samym tekście drukarz wspominał też o życzliwości, którą okazywał mu Batory. Wzmiankując „one miłościwe i łaskawe przez listy wskazywania do mnie"7, Januszowski miał może na myśli jakieś zlecenia czy życzenia królewskie, kierowane do niego bezpośrednio albo (co bardziej prawdopodobne) przekazywane mu przez urzędników stojących blisko władcy. Na przykład 12 lipca 1586 roku Batory pisał z Grodna do podskarbiego Hiacyntna Młodziejowskiego: „librum patris Bellarmini, quem volumus, ut istic Cracoviae elegantioribus typis excudi curet, nobisque 200 exemplaria mittat. Qua de re transiget cum Januszewski typographo"8.

Z archiwów wydobyto też i w większości wydano garść listów pisanych przez Januszowskiego. Są to epistulae do kanclerza i hetmana Jana Zamoyskiego, kanclerza Lwa Sapiehy, księdza Tomasza Płazy, biskupa warmińskiego Marcina Kromera i relacja o sejmie inkwizycyjnym, której adresata nie znamy9. Wszystkie te listy - oprócz ostatniego wymienionego - dotyczą wydawniczych zatrudnień Łazarzowica. Ponieważ ich treść oraz ukształtowanie stylu i języka omówiono w książce o Januszowskim, przypomnijmy tu tylko, że wcześniejsze listy Januszowskiego $\mathrm{z}$ lat 80 . XVI wieku, pozostały $\mathrm{z}$ korespondencji, którą drukarz utrzymywał z biskupem Marcinem Kromerem i jego sekretarzem księdzem Tomaszem Płazą; późniejsze, pochodzące już z przełomu stuleci, są śladem kontaktów Łaza-

6 Ibidem, k. A2r.

7 Ibidem, k. B1v.

8 Cyt. za: J. Ptaśnik, Monumenta Poloniae typographica, Lwów 1922. W tłumaczeniu K. Gary: „chcemy, by zadbał o wydanie książki ojca Bellarmina tu, w Krakowie, bardziej elegancką czcionką i wysłał nam 200 egzemplarzy. W tej sprawie zawrze umowę z drukarzem Januszewskim".

9 Wykaz listów Januszowskiego zob. J. Kiliańczyk-Zięba, Czcionką..., s. 343-344. 
rzowica z Janem Zamoyskim i Lwem Sapiehą. Z Kromerem i Płazą Januszowski dyskutował o kwestiach związanych z publikacją mszału warmińskiego. Sapieże przedstawił projekt edycji praw litewskich, a z Zamoyskim omawiał sprawy dotyczące wyposażenia oficyny zamojskiej i relacjonował własne niepowodzenia na polu wydawniczym, prosząc hetmana o wsparcie ${ }^{10}$.

Przedstawiane w niniejszej edycji listy Januszowskiego to przeoczony dotąd, niewydany jeszcze fragment epistolograficznej spuścizny krakowskiego drukarza: łaciński list do biskupa Marcina Kromera i polski do jego plenipotenta księdza Tomasza Płazy. Istnienie obu odnotował już Stanisław Bodniak w artykule poświęconym zabiegom Januszowskiego wokół publikacji ksiąg kościelnych ${ }^{11}$. Tekstowi Bodniaka towarzyszył przedruk umowy na druk mszału warmińskiego (Januszowski zawarł ją z Płazą działającym jako pełnomocnik Kromera) oraz edycja listu, z którym drukarz wysłał duchownemu projekt kontraktu. Wzmianki Bodniaka o pozostałych dwóch listach Łazarzowica znajdujących się wśród kromerianów przeoczyła jednak Alodia Kawecka-Gryczowa. Z kolei w książce Czcionką i piórem. Jan Januszowski w roli pisarza i tłumacza, rejestrując prace pisarskie Januszowskiego, odnotowano tylko istnienie listu drukarza do biskupa warmińskiego ${ }^{12}$.

Oba wydawane obecnie listy są odpryskiem szerokiej zapewne korespondencji Januszowskiego, która powstała w związku z jego staraniami, by dla polskich diecezji księgi kościelne tłoczono w Drukarni Łazarzowej. Podczas soboru trydenckiego postanowiono ujednolicić liturgię przez opracowanie i wydanie mszału rzymskiego i brewiarza rzymskiego dla całego Kościoła (reformę rytuału odłożono na

10 Ibidem, s. 44.

11 S. Bodniak, W oficynie „architypografa”. Rzecz o kłopotach Januszowskiego, „Silva Rerum” 5 (1930), s. 138-143.

12 A. Kawecka-Gryczowa, Jan Januszowski, s. 97 („Bibliografia prac i listów”); J. Kiliańczyk-Zięba, Czcionką..., s. 343-344. 
później) $^{13}$. Januszowski oczywiście wiedział, że za tą decyzją szły zlecenia na druk zreformowanych ksiąg, stanowiących dla typografów, którzy otrzymali na nie przywileje, źródło znacznego i stałego dochodu. Inspiracją dla krakowskiego drukarza mógł być sukces Christopha Plantina. Z antwerpskiej oficyny Plantina (a potem i jego następców) wychodziły wznawiane edycje ksiąg liturgicznych dla diecezji europejskich i zamorskich terytoriów pod panowaniem Hiszpanii dziesiątki tysięcy egzemplarzy, które w 1572 roku tłoczyło aż dwanaście pras ${ }^{14}$. Oczywiście rynek, o którego zaopatrzeniu mógł myśleć Januszowski, był nieporównywalnie mniejszy, jednak jego zmonopolizowanie byłoby bardzo zyskowne. Planując druk książek liturgicznych dla diecezji w Rzeczypospolitej, Januszowski zdobył „obietnicę pieniężnej pomocy ze strony biskupów i przywilej królewski (29 V 1583 r.), warujący mu wyłączność druku i sprzedaży brewiarza i mszałów podług uchwał soboru trydenckiego - w Polsce i Litwie"15. Zabiegi Łazarzowica, by pozyskać zlecenia od prymasa Stanisława Karnkowskiego i biskupów, początkowe sukcesy drukarza, a potem jego rozczarowanie opisał niegdyś pokrótce Stanisław Bodniak. W ni-

$13 \mathrm{O}$ zabiegach zmierzających do ujednolicenia liturgii w Kościele zachodnim i powstawaniu ksiąg w związku z tym procesem zob. P.M. Gy, L'Unification liturgique de l'Occident et de la liturgie de la Curie Romaine, „Revue des Sciences Philosophiques et Théologiques" 59 (1975), s. 601-612; C. Dondi, Books of Hours. The Development of the Texts in Printed Form, w: Incunabula and Their Readers, ed. by K. Jensen, London 2003, s. 56-57, s. 214; N.K. Rasmussen, Liturgy and Liturgical Arts, w: Catholicism in Early Modern History. A Guide to Research, ed. by J.W. O'Malley, St. Luis 1988, s. 273-297; K.L. Bowen, Christopher Plantin's Book of Hours. Illustration and Production, Nieuwkoop 1997, s. 63-64.

14 L. Voet, The Golden Compasses. A History and Evaluation of the Printing and Publishing Activities of the Officina Plantiniana at Antwerp, vol. 1: Christophe Plantin and the Moretuses. Their Lives and Their World, Amsterdam 1969, s. 65-69; R.M. Kingdon, Patronage, Piety, and Printing in Sixteenth-Century Europe, w: idem, Church and Society in Reformation Europe, London 1985, s. 22-35; idem, The Plantin Breviaries. A Case Study in the Sixteenth-Century Business Operations of a Publishing House, w: idem, Church..., s. 133-150.

15 S. Bodniak, W oficynie..., s. 139; Privilegia Typographica Polonorum. Polskie przywileje drukarskie 1493-1793, oprac. i wyd. M. Juda, Lublin 2010, nr 67, s. 97-98. 
niejszym wstępie nie ma miejsca na szczegółową rekonstrukcję starań Januszowskiego, które obejmowały i osobiste spotkania $\mathrm{z}$ dygnitarzami i ich zaufanymi ludźmi, i „listowne rozmowy”. Przywołując historyczny kontekst, w którym wydawane listy Januszowskiego powstały i którego znajomość jest konieczna, by zrozumieć ich treść, warto jedynie wyjaśnić, że jednym z najbardziej energicznych orędowników posoborowej odnowy w Królestwie Polskim był Marcin Kromer. Na długo przed przyjęciem uchwał soboru trydenckiego przez synod piotrkowski w 1577 roku podjęto z inicjatywy Kromera prace nad reformą liturgii godzin i rytuałów w diecezji warmińskiej. Diecezja ta nie podlegała arcybiskupowi gnieźnieńskiemu, ale po rozpadzie metropolii ryskiej traktowana była jako bezpośrednio zależna od Stolicy Apostolskiej ${ }^{16}$. W rezultacie starań biskupa Kromera powstały i wydrukowane zostały (w kolońskiej oficynie Maternusa Cholinusa) brewiarz warmiński (Breviarium Varmiense, 1581), a wcześniej także agenda sakramentalna (Agenda sacramentalia, 1574) i agenda ceremonialna (Agenda ceremonialia, 1578) ${ }^{17}$. Uwzględniając postulaty soboru i akomodując ryt rzymski, opierały się one na zwyczajach warmińskich, a oprócz łaciny używały także polszczyzny i niemieckiego. Było to możliwe, ponieważ bulla Piusa V pozwalała diecezjom, które miały własne księgi dłużej niż dwieście lat, sprawować liturgię według dawnych obrzędów. Podobną strategię Kromer przyjął także dla mszału: dysponując wzorcem w postaci Missale Romanum opublikowanego w 1570 roku, zdecydował o połączeniu na Warmii „rytu warmińskiego z rzymskim. Kanon oraz układ zaczerpnął z tego drugiego, natomiast zatrzymał z małymi wyjątkami z mszału warmińskiego formularze mszalne, lekcje, nuty i obrzędy roku liturgicznego"18.

16 W. Müller, Struktura organizacyjna diecezji rzymskokatolickich w Polsce w XVI-XVIII wieku, w: Księga tysiąclecia katolicyzmu w Polsce, red. M. Rechowicz, Z. Sułowski, Lublin 1969, s. 95.

17 W. Nowak, Geneza Agendy biskupa Marcina Kromera, „Studia Warmińskie” 6 (1969), s. 173-209.

18 W. Nowak, Biskup Marcin Kromer jako liturgista, w: Marcin Kromer i jego czasy (1512-1589), red. S. Achremczyk, Olsztyn 2012, s. 176 (ten sam artykuł także w: „Komunikaty Warmińsko-Mazurskie” 212 (2012), s. 571-594). 
W czasie gdy kustosz katedry we Fromborku Samson z Woryn pracował na zlecenie Kromera nad treścią i układem nowego mszału warmińskiego, zastanawiano się nad kompozycją mszałów dla innych diecezji i myślano o ich produkcji. Prymas Stanisław Karnkowski powołał kolegium liturgistów do opracowania missale dla wszystkich diecezji i zabiegał o odpowiednie fundusze ${ }^{19}$. Księgę dla całej prowincji gnieźnieńskiej miała tłoczyć Drukarnia Łazarzowa. Planów prymasa nie udało się jednak zrealizować ${ }^{20}$. Ostatecznie Drukarnia Łazarzowa wytłoczyła tylko Missale Varmiense (w 1587 r.) oraz powtarzane wydania agendy Hieronima Powodowskiego ${ }^{21}$.

Oba wydawane tutaj listy Jana Januszowskiego powstały zanim Łazarzowic podpisał z Tomaszem Płazą umowę na druk mszału warmińskiego (co nastąpiło 8 sierpnia 1586 r.) i w czasie, gdy nie było jeszcze jasne, czy od razu tłoczyć się nie będzie księgi dla całej prowincji gnieźnieńskiej. Starszy z listów, datowany 14 listopada 1585 roku, Januszowski wysłał do Marcina Kromera. Powołując się na rozmowy, które od jakiegoś już czasu prowadził z sekretarzem biskupa, księdzem Tomaszem Płazą, i z profesorem Akademii Krakowskiej, a zarazem kanonikiem krakowskiej kapituły, Marcinem Glicjuszem z Pilzna, drukarz zalecał zwierzchnikowi diecezji warmińskiej swoje usługi i prosił o zakończenie negocjacji dotyczących produkcji mszału.

Późniejszy z udostępnianych tutaj listów Januszowski napisał do Tomasza Płazy, w czasie gdy obaj czekali na decyzję kapituły krakowskiej, która bez zgody biskupa Piotra Myszkowskiego nie chciała zezwolić na druk mszału warmińskiego. List jest niedatowany, ale prawdopodobnie powstał w kwietniu 1586 roku. Datację umożliwia list Płazy do Kromera z 25 kwietnia tego roku, w którym proboszcz św. Szczepana pisał do biskupa o tych samych sprawach, w których

19 P. Sczaniecki, Stużba Boża $w$ dawnej Polsce. Studia o Mszy Świętej, seria druga, Poznań 1966, s. 137-147.

20 W. Nowak, Biskup..., s. 174-175.

21 T.L. Pietras, Produkcja katolickiej książki liturgicznej w Polsce od końca XV do połowy XVII wieku, „Archiwa, Biblioteki i Muzea Kościelne” 39 (1979), s. 171-189 (cz. 1); „Archiwa, Biblioteki i Muzea Kościelne” 41 (1980), s. 191-245 (cz. 2). 
nagabywał go Januszowski. Płaza donosił Kromerowi o przekazanej mu przez Marcina Glicjusza z Pilzna wiadomości, że kapituła krakowska kazała Januszowskiemu wstrzymać się z drukowaniem mszału warmińskiego, że kanonicy czekają „rezolucyjej” biskupa Myszkowskiego i że zwrócili się do zarządców innych diecezji polskich „aby in suis capitulis już koniecznie postanowili o drukowanie mszała pro tota provincia" ${ }^{\prime 2}$. Płaza informował też w owym liście swego mocodawcę, że nie zlecił jeszcze produkcji papieru na obszerną księgę. Swoją decyzję uzasadniał wprost: „a co wiedzieć, jeśli dadzą drukować biskupi ty mszały, albo jeśli [...] W. M. nie odmienisz woli swojej a nie poślesz gdzie indzie, jeśli biskup nie dopuści drukować" ${ }^{23}$. Generalne posiedzenie kapituły krakowskiej zwyczajowo odbywało się w maju „pro festo Sancti Stanislai”. Januszowski i Płaza oczekiwali, że kanonicy i biskup po pierwsze zgodzą się na produkcję mszału warmińskiego, po drugie zaś, że podejmą wiążące (i inspirujące dla zarządców innych diecezji polskich) decyzje dotyczące druku księgi dla całego arcybiskupstwa gnieźnieńskiego. Ostatecznie w maju 1586 roku kapituła zaaprobowała plany Januszowskiego ${ }^{24}$, a biskup Myszkowski zgodził się na produkcję mszału warmińskiego w drukarni znajdującej się na terenie jego diecezji, choć sam nie zamierzał fundować missale Cracoviense. Płaza donosił o tych wydarzeniach Kromerowi w liście z początku czerwca:

[...] z strony mszała. J.M. Ksiądz Biskup rozkazał, aby był drukowany. „Bo jeśli - prawi - wolno drukować heretyckie rzeczy, czemu nie ma być wolno mszałów drukować" [...]. Aby sam miano drukować mszał pro tota provincia, nie trzeba się spodziewać. Powiedział ksiądz Cracoviensis, iż na to nie da nic. „Mam swój mszał. Jeśli kto nie ma, niechaj sobie kupi warmieński etc.” ${ }^{35}$.

22 T. Płaza, list do M. Kromera (25 IV 1586), Archiwum Archidiecezji Warmińskiej w Olsztynie (AAWO), AB, D 35, k. 90-91.

23 Ibidem.

24 Acta actorum Capituli Cracoviensis, vol. 7, f. 53, za: W. Budka, Drugie dopetnienie wydawnictwa Monumenta Poloniae Typographica, „Silva Rerum” 3 (1927), s. $42-43$.

25 T. Płaza, list do M. Kromera (6 VI 1586), AAWO, AB D 35, k. 88r. 
Zarówno łacińska epistoła, którą Januszowski posłał do biskupa Kromera, jak i notatka, którą zaadresował do księdza Płazy, to listy prywatne (genus familiare), służące w pierwszym rzędzie informowaniu ${ }^{26}$. Oba teksty są rzeczowe i skoncentrowane na sprawach praktycznych. Zachowują poprawność gramatyczną, ale ich autor nie posługuje się artystycznymi środkami wyrazu (wyjątkiem jest ocena własnych kompetencji typografa, którą Januszowski sformułował w łacińskim liście: „non ita enim aversus a nobis sol est [...]”). Korespondencja, którą drukarz skierował do biskupa, jest utrzymana $\mathrm{w}$ odpowiadającym pozycji adresata powściągliwym tonie, zaopatrzona we właściwe formuły salutacji i inskrypcji, oficjalna. Niedatowany polskojęzyczny list Januszowskiego do Płazy stanowi pośpieszną odpowiedź na otrzymane odeń wiadomości. Przypomina (pod wzgędem stylu) i zastępuje (pod względem funkcji) rozmowę znajomych. Podobny jest w tym do drugiego znanego listu drukarza do kanonika wiślickiego, w którym Januszowski wskazywał na cel korespondencji z duchownym, pisząc: „chociaż przez kartki, przecię się, da Pan Bóg, zmówić będziem mogli”27.

Nie wiadomo, czy Januszowski zbierał „kartki”, które do niego napływały. Czyniła to kancelaria Marcina Kromera i dlatego przechowały się dla nas i list drukarza do biskupa, i dwa listy Łazarzowica do Płazy, które adresat posłał swemu patronowi wraz z własnym „pisaniem”. Przekazywanie osobom trzecim otrzymanych listów (albo ich kopii) było współcześnie powszechne. „Trudno powiedzieć, czy chodziło tu o oszczędność czasu i papieru, czy o podkreślanie pełnej lojalności korespondenta, który wykazywał w ten sposób, że nie ma nic do ukrycia, jeśli idzie o swe własne kontakty"28. Owych załącz-

26 M. Mejor, Epistolografia renesansowa (uwagi wstępne), w: Listowne Polaków rozmowy. List łacińskojęzyczny jako dokument polskiej kultury XVI i XVII wieku, red. J. Axer, J. Mańkowski, Warszawa 1992, s. 11.

27 J. Januszowski, list do T. Płazy (21 IV 1586), cyt. za: Bodniak S., W oficynie..., s. 142 .

28 W. Tygielski, Epistolografia staropolska jako źródło do badania mechanizmów politycznych, „Odrodzenie i Reformacja w Polsce” 33 (1988), s. 74. 
ników w większości jednak nie znamy, co listy Januszowskiego do Płazy zachowane wśród archiwaliów Marcina Kromera czyni tym ciekawszymi zabytkami dawnej kultury.

Oba wydawane tutaj listy Januszowskiego są przede wszystkim cennym źródłem do poznania dziejów polskiej książki w XVI wieku. Zawierają mnóstwo drobnych, ale zajmujących szczegółów. W liście do biskupa Kromera znajdujemy na przykład wzmiankę o tym, że Drukarnię Łazarzową zwiedzał Stanisław Hozjusz, jeszcze jeden (obok kasztelana żarnowieckiego Jana Myszkowskiego i księcia Konstantego Ostrogskiego) znakomity gość, który ciekawy był urządzenia krakowskiej oficyny ${ }^{29}$. Z kolei końcowy ustęp listu do Tomasza Płazy informuje, ile czasu potrzeba było, by zrealizować zamówienie na papier dla obszernego tomu in folio. Czytane razem, a lepiej jeszcze studiowane $\mathrm{w}$ zestawieniu $\mathrm{z}$ archiwaliami udostępnionymi przez Bodniaka i czekającymi na wydanie listami Tomasza Płazy do Marcina Kromera ${ }^{30}$, okazują się świadectwem długotrwałych, emocjonujących zabiegów, które poprzedzały druk jedynego wytłoczonego w Rzeczypospolitej mszału potrydenckiego; przynoszą wiadomości o stojących za tak dużym przedsięwzięciem ludziach i ich relacjach; informują o uwarunkowaniach organizacyjnych produkcji liturgicznej książki w polskiej drukarni. Są przyczynkiem do odtworzenia zależności między kulturą a władzą, zrozumienia mechanizmów mecenatu i ówczesnej mentalności.

29 Zob. J. Kiliańczyk-Zięba, Czcionką..., s. 23-24. O odwiedzinach ważnych osobistości w antwerpskiej drukarni Plantina zob. na przykład B. Górska, Krzysztof Plantin i Officina Plantiniana, Wrocław 1989, s. 303-308.

30 K. Stasiewicz, Korespondencja Tomasza Płazy z Marcinem Kromerem, „Odrodzenie i Reformacja w Polsce” 33 (1978), s. 167-185. 


\section{Edycja}

\section{Opis źródeł i zasady wydania}

Oba listy zachowały się w Archiwum Archidiecezji Warmińskiej w Olsztynie.

List do Tomasza Płazy, sygn. AAWO, AK, D 39, k. 92. Na verso karty adres: „Jego M. X. Płazie do rąk własnych”. Pieczątka sygnetowa Januszowskiego wyciśnięta w papierze (zielony wykruszony wosk) przedstawiająca w otoku rękę trzymającą pochodnię, nad otokiem litery I. L. I. (Ioannes Lazarides Ianussovius). List do Marcina Kromera, sygn. AAWO, AK, Ab 5, k. 189, 189v.

List polski wydano, opierając się na instrukcji Zasady wydawania tekstów staropolskich. Projekt (Wrocław 1955) dla wydawnictw tekstów nowożytnych typu B. Podjęto następujące decyzje szczegółowe:

- rozwinięto skróty utartych tytulatur (np. W. M. jako Wasza Miłość, choć M. mogło też oznaczać Mość), ale nie rozwinięto zagadkowego W. M. S. otwierającego polskojęzyczny list Januszowskiego;

- rozwinięto skróty typu krakf $\rightarrow$ krakowskiej;

- zachowano konsekwentnie beznosówkową pisownię sie;

- zgodnie z grafią rękopisu nie kreskowano o (np. mogł, poki);

- nie zachowano oznaczania pochyleń $a$;

- ij transkrybowano jako $i$;

- wprowadzono znaki diakrytyczne (np. drukowac $\rightarrow$ drukować);

- zmodernizowano pisownię wielkich i małych liter (np. w nagłówku listu);

- obocznie wystepujące $l \mathrm{i} \nmid \mathrm{w}$ miejscu dzisiejszego $\nmid$ zmodernizowano;

- partykułę ci pisano rozdzielnie (np. tak ci jest), -ć - łącznie (np. dobrzeć). 
W tekście łacińskim:

- rozwinięto bez zaznaczania oczywiste skróty (np. Dne $\rightarrow$ Domine, mihiq $\rightarrow$ mihique);

- podobnie w przypadku skrótów utartych tytulatur (np. $P . \rightarrow$ Paternitas);

- akcentów nad samogłoskami nie zaznaczono (np. cùm $\rightarrow$ cum);

- ligatury oddano pełnym wyrazem (np. \& $\rightarrow$ et; $\beta \rightarrow s s$ );

- spółgłoskowe $u$ oddano jako $v$ (np. breuiter $\rightarrow$ breviter);

- dyftongi zapisane jedną samogłoską podano w klasycznej formie (np. $e \rightarrow a e$ );

- w przypadku wielkich i małych liter zachowano pisownię oryginalną;

- błędne formy zaznaczono w przypisach.

Listy

Moj Łaskawy Ksze Kanoniku'31!

W. M. S. ${ }^{32}$

Wskazać Wasza Miłość raczył do mnie, że sie z drukowaniem mszału zatrzymać musi aż do kapituły przyszłej krakowskiej ${ }^{33}$, a że sie teraz nic stanowić nie może. Tak ci jest, dobrzeć sie zatrzymać: i ja też wolę, i tak sie z Ich Miłościami księżą kanoniki postanowiło; bo od czego Pan Bog, że sie, da Pan Bog, co dobrego sprawić będzie mogło dla wszytkiej prowincyjej ${ }^{34}$. Ale zaś z drugiej strony trzeba sie na to obejźrzeć, żeć ten mszał odmienić sie nie będzie mogł, bo tak

31 Ksze Kanoniku - księże kanoniku; Tomasz Płaza (ok. 1512/30-1593) był proboszczem w parafii św. Szczepana w Krakowie i członkiem kapituły (zgromadzenia) duchownych przy kolegiacie w Wiślicy.

32 W. M. S. - być może: Waszej Miłości służba lub Waszej Miłości salutem.

${ }^{33}$ Kapituły przyszłej krakowskiej - chodzi o obrady kanoników kapituły katedralnej na Wawelu, która spotykała się trzy razy do roku, między innymi na święto św. Stanisława (przypadające 8 maja).

${ }^{34}$ dla wszytkiej prowincyjej - dla całej archidiecezji gnieźnieńskiej 
rozumiem, że Jego Miłość Ksiądz Biskup Warmieński nie temere ${ }^{35}$ sie tego ważył, że wedle starego obyczaju nabożeństwo sobie zostawił, ale podobno cum consensu et authoritate summi pontificis ${ }^{36}$. Co jeśliż tak jest, tedy rzecz pewna, drukować sie będzie musiał tak jako jest, na osobnej prasie, a dla prowincyjej wszytkiej, gdzieby sie też Ich Miłoście ${ }^{37}$ zgodzili, na drugiej. A gdzieby też więc mszał warmieński drukować sie miał wedle rzymskiego podania, żeby sie już zgodził i dla wszytkiej prowincyjej polskiej, tedy przecię drukować sie ma, a miałby sie począć zarazem po kapitule krakowskiej. Co by żadnym sposobem być nie mogło: prze tę przyczynę, że by dopiero papir dla tego gotować ${ }^{38}$. Otoż ja tak rozumiem, i zdałoby mi sie nie od rzeczy, ponieważ mszał ktoryżkolwiek z tych drukować sie ma, aby sie temi czasy niżeli kapituła przypadnie krakowska, papir gotować dał; bo jeśliż go robić nie damy, nie trzeba w tym wętpić, aby ondzie po kapitule nie musiało się czekać przynamniej czterzech albo piąci niedziel $^{39}$. A temi czasy też co nam dzień wielki ${ }^{40}$ ubieży, to ubieży, bo za czterzy niedziele wiele dobrego sprawić by sie mogło ${ }^{41}$. Tom chciał Waszej Miłości oznajmić, abyś mi Wasza Miłość znać dał, czego by sie trzymać. Bo ile baczę, jeśliż sie robić ma, tedy papiru trzeba, ktory jeśliż sie potym ma dać robić, czemu nie teraz, poki czas prożny ${ }^{42}$ ? Proszę, namyśl sie Wasza Miłość, a daj znać.

Waszej Miłości powolny

Januszowski

35 temere - przypadkowo, nieprzemyślanie

36 cum consensu et authoritate summi pontificis - za zgodą i powagą najwyższego kapłana (papieża)

37 Ich Miłoście - kanonicy kapituły krakowskiej i biskup Piotr Myszkowski.

38 gotować - przygotowywać, zrobić

39 niedziel - tygodni

40 wielki - długi, jasny

41 Januszowskiemu chodzi o to, by nie zmitrężyć wiosenno-letnich miesięcy, gdy w drukarni można było pracować cały dzień przy słonecznym świetle.

${ }^{42}$ próżny - wolny 
Reverendissime in Christo Pater et Domine Domine clementissime!

Cum et Venerabilis Dominus Plasa et Reverendus Dominus Pilzno (quod rei maiorem fecit fidem) Reverendissimae Paternitatis Vestrae nomine mecum diligenter egissent, mihique ut in eorum sententiam abirem persuasissent, ut in excudendo dioecesis Varmiensis Missali operam meam diligentiamque praestarem, ita, quod sciam, convenimus, ut in quadringenta exemplaria chartam meam communem ego darem et operam, mihi autem in chartas singulas, quotquot singulis in exemplaribus essent, singuli semigrossi numerarentur. Ita enim et magnae impensae parsum, et me damno auctum maximo ne queri possem quoquomodo provisum est. Cumque propterea magno accersitis domum operariis diutius expectarem, coepissem cum diuturnum hoc silentium, tum Plasae cunctationem habere suspectam, ne mihi maiori dispendio res esset, non dubitavi ad Reverendissimam Paternitatem Vestram ipse scribere et si quid in eo genere a Reverendissima Paternitate Vestra expectandum esset cominus sciscitari atque discere. Praesertim cum Generosus Dominus Hosius, Secretarius Regius huc iter ornaret, qui domum meam non tantum alia de causa venisset, sed pene omnium officinae meae partium spectator fuisset non inelegans. De hoc itaque Missali, si quid certi Reverendissima Paternitas Vestra cum animo constituit suo, meque ad illud adornandum legit Typographum, (ut quidem pro sua in maiores meos benevolentia facere cogitavit, et eorum in se meritis debuit) ut me breviter, quod sine ips $<\mathrm{i}>\mathrm{us}^{43}$ Reverendissim[a] e Paternitatis molestia fiat, certiorem facere velit, vehementer etiam atque etiam rogo. Scio quidem me illos, qui et Reverendissimae Paternitatis Vestrae antecessoribus, et huic Ecclesiae praestantem operam navarunt, adaequare non posse; diligentia tamen, ac singulari in professionem Catholicam studio, ne vivam, si quemquam patiar anteire. Quamquam et ornatum typorum quod attinet, efficerem, is quoque ut esset, quem vel adversarii probare merito possent. Non ita

${ }^{43} \mathrm{~W}$ oryginale ipsus. 
enim aversus a nobis sol est, quin si facultatibus, simus, etiam elegantia pares omnibus esse possimus. Sed haec Reverendissima Paternitas Vestra pro sua sapientia melius viderit, statueritque, cui me omniaque mea quam maxime esse commendata cupio. Valeat Reverendissima Paternitas Vestra. Datum Cracoviae 19 Novembris 1585.

Reverendissimae Paternitatis Vestrae deditissimus

Joannes Janussovius Lazarides

\section{Przekład}

Przewielebny w Chrystusie, Ojcze i Księże, Księże najłaskawszy!

Skoro i czcigodny ksiądz Płaza i wielebny ksiądz Pilzno ${ }^{44}$ (co rozbudziło moją większą wiarę dla tej sprawy) w Twoim imieniu, Przewielebny Ojcze, dokładnie mi wyłuszczyli i przekonali do swojego zdania, abym podjął ten trud i zadbał o druk mszału diecezji warmińskiej, zatem, o ile mi wiadomo, uzgodniliśmy, że na czterysta egzemplarzy dam mój zwykły papier ${ }^{45}$ i zajmę się [ich drukiem], a za każdy arkusz, tyle ile jest w każdym egzemplarzu, zapłacone mi będzie pół grosza. Tak bowiem na wszelaki sposób starano się zapobiec dużym wydatkom, a i ja nie będę mógł narzekać, że poniosę wielkie straty. Dlatego, kiedy dość długo czekałem z wezwanymi do domu rzemieślnikami, zaczęło wydawać mi się podejrzane zarówno to długotrwałe milczenie, jak i opieszałość Płazy. Zatem żeby to przedsięwzięcie nie przyniosło mi jeszcze większych strat, nie wahałem się sam napisać do Przewielebnego Ojca i bezpośrednio wypy-

44 Ksiądz Pilzno - Marcin Glicjusz z Pilzna (1528-1591), kanonik kapituły katedry krakowskiej, profesor i rektor Akademii Krakowskiej.

${ }_{45}$ Zwykły papier - charta communis to określenie wielkości papieru, por. list J. Januszowskiego do T. Płazy z 21 kwietnia 1586 roku: „papir pospolity być miał. Teraz iż papir więtszy ...”; Umowa z Panem Januszowskim z strony drukowania mszałów pro Dioecesi Varmien. etc.: „a papir ma być medjan mały, który jest palcem i coś więtszy i szerszy niźli ów pospolity" (cyt. za: S. Bodniak, W oficynie..., s. $142-143)$. 
tać i dowiedzieć się, czy można się od Przewielebnego Ojca czegoś $\mathrm{w}$ tej sprawie spodziewać. Zwłaszcza że [niegdyś] przybył tu z wizytą szlachetny ksiądz Hozjusz ${ }^{46}$, sekretarz królewski, który odwiedził mój dom nie $\mathrm{z}$ innego powodu, jak tylko by ze znawstwem obejrzeć niemal całą moją drukarnię. Zatem o tym mszale: jeśli rzeczywiście Przewielebny Ojciec powziął decyzję i do jego przygotowania wybrał mnie jako drukarza (co przez wzgląd na swoją dla moich przodków ${ }^{47}$ łaskawość postanowił uczynić i co w uznaniu dla ich zasług dla siebie powinien był zrobić), niech zechce mnie rychło powiadomić, co Przewielebnemu Ojcu nie sprawi kłopotu, a o co ustawicznie i gorąco proszę. Wiem zaiste, że nie zdołam dorównać tym, którzy oddali wybitne zasługi poprzednikom Przewielebnego Ojca i temu Kościołowi. Ale niech zginę, jeśli pozwolę się komuś wyprzedzić w gorliwości i szczególnym oddaniu wierze katolickiej! Jednakowoż, jeśli idzie o ozdobność czcionek, przygotowałbym takie, które nawet przeciwnicy mogliby słusznie pochwalić. Nie odwróciło się bowiem od nas słońce aż tak, żebyśmy odpowiednio wyposażeni, gustownością nie mogli dorównać wszystkim innym. Ale to Przewielebny Ojciec podług własnej mądrości lepiej rozważy i postanowi, któremu siebie i wszystkie moje sprawy najgoręcej pragnę polecić. Bądź zdrów, Przewielebny Ojcze. Dane w Krakowie, 19 listopada 1585 roku.

Przewielebnemu Ojcu

Wielce oddany

Jan Januszowski Łazarzowic

46 Ksiądz Hozjusz - Stanisław Hozjusz (1504-1579), sekretarz Zygmunta Starego, biskup warmiński, kardynał Kościoła katolickiego, płodny pisarz.

47 Moich przodków - drukarnia, którą po ojcu odziedziczył Januszowski, tłoczyła pod rządami najpierw Wietora, a potem Andrysowica zarówno prace Hozjusza, jak i Kromera. 


\section{Bibliografia}

\section{Źródła archiwalne i drukowane}

Archiwum Archidiecezji Warmińskiej w Olsztynie (AAWO), AB, D 35; AK, D 39; $\mathrm{AK}, \mathrm{Ab} 5$.

Januszowski J., [list dedykacyjny do Jana Myszkowskiego], w: Jan Kochanowski, Kraków: Drukarnia Łazarzowa, 1585/1586.

Januszowski J., Nowy karakter polski, Kraków: Drukarnia Łazarzowa, 1594.

Kochanowski J., Dzieła wszystkie, Wydanie sejmowe, tom wstępny: Wprowadzenie wydawnicze, oprac. M.R. Mayenowa, J. Woronczak, M. Kaczmarek, E. Głębicka (Biblioteka Pisarzów Polskich, seria B, nr 22), Wrocław 1983.

Privilegia Typographica Polonorum. Polskie przywileje drukarskie 1493-1793, oprac. i wyd. M. Juda, Lublin 2010.

Ptaśnik J., Monumenta Poloniae typographica, Lwów 1922.

\section{Opracowania}

Bodniak S., W oficynie „architypografa”. Rzecz o kłopotach Januszowskiego, „Silva Rerum" 5 (1930), s. 138-143.

Bowen K.L., Christopher Plantin's Book of Hours. Illustration and Production, Nieuwkoop 1997.

Budka W., Drugie dopetnienie wydawnictwa Monumenta Poloniae Typographica, „Silva Rerum” 3 (1927).

Dondi C., Books of Hours. The Development of the Texts in Printed Form, w: Incunabula and Their Readers, ed. by K. Jensen, London 2003.

Górska B., Krzysztof Plantin i Officina Plantiniana, Wrocław 1989.

Gy P.M., L'Unification liturgique de l'Occident et de la liturgie de la Curie Romaine, „Revue des Sciences Philosophiques et Théologiques” 59 (1975), s. 601-612.

Kawecka-Gryczowa A., Jan Januszowski, w: Drukarze dawnej Polski od XV do XVIII wieku, t. 1: Małopolska, cz. 1: Wiek XV-XVI, red. A. Kawecka-Gryczowa, Wroclaw 1983, s. 69-99.

Kiliańczyk-Zięba J., Czcionka i piórem. Jan Januszowski w roli pisarza i tłumacza, Kraków 2007.

Kingdon R.M., Patronage, Piety, and Printing in Sixteenth-Century Europe, w: idem, Church and Society in Reformation Europe, London 1985, s. 22-35.

Kingdon R.M., The Plantin Breviaries. A Case Study in the Sixteenth-Century Business Operations of a Publishing House, w: idem, Church and Society in Reformation Europe, London 1985, s. 133-150. 
Mejor M., Epistolografia renesansowa (uwagi wstępne), w: Listowne Polaków rozmowy. List łacińskojęzyczny jako dokument polskiej kultury XVI i XVII wieku, red. J. Axer, J. Mańkowski, Warszawa 1992.

Müller W., Struktura organizacyjna diecezji rzymskokatolickich $w$ Polsce $w$ XVIXVIII wieku, w: Księga tysiąclecia katolicyzmu w Polsce, red. M. Rechowicz, Z. Sułowski, Lublin 1969.

Nowak W., Biskup Marcin Kromer jako liturgista, w: Marcin Kromer i jego czasy (1512-1589), red. S. Achremczyk, Olsztyn 2012 (ten sam artykuł także w: „Komunikaty Warmińsko-Mazurskie” 212 (2012), s. 571-594).

Nowak W., Geneza Agendy biskupa Marcina Kromera, „Studia Warmińskie” 6 (1969), s. 173-209.

Pietras T.L., Produkcja katolickiej książki liturgicznej w Polsce od końca XV do połowy XVII wieku, „Archiwa, Biblioteki i Muzea Kościelne” 39 (1979), s. 171-189 (cz. 1); „Archiwa, Biblioteki i Muzea Kościelne” 41 (1980), s. 191-245 (cz. 2).

Rasmussen N.K., Liturgy and Liturgical Arts, w: Catholicism in Early Modern History. A Guide to Research, ed. by J.W. O'Malley, St. Luis 1988, s. 273-297.

Sczaniecki P., Służba Boża w dawnej Polsce. Studia o Mszy Świętej, seria druga, Poznań 1966.

Stasiewicz K., Korespondencja Tomasza Płazy z Marcinem Kromerem, „Odrodzenie i Reformacja w Polsce” 33 (1978), s. 167-185.

Tygielski W., Epistolografia staropolska jako źródło do badania mechanizmów politycznych, „Odrodzenie i Reformacja w Polsce” 33 (1988).

Voet L., The Golden Compasses. A History and Evaluation of the Printing and Publishing Activities of the Officina Plantiniana at Antwerp, vol. 1: Christophe Plantin and the Moretuses. Their Lives and Their World, Amsterdam 1969.

Zurkowa R., Jan Januszowski, w: Drukarze dawnej Polski od XV do XVIII wieku, t. 1: Małopolska, cz. 2: Wiek XVII-XVIII, vol. 1, red. J. Pirożyński, Kraków 2000, s. $250-257$.

Żurkowa R., Łazarzowa Drukarnia, w: Drukarze dawnej Polski od XV do XVIII wieku, t. 1: Małopolska, cz. 2: Wiek XVII-XVIII, vol. 2, red. J. Pirożyński, Kraków 2000, s. 411-412. 